\title{
Производни абстрактни съществителни имена в българските диалекти
}

\author{
Владислав МилАнов \\ Софийски университет „Св. Климент Охридски” \\ vladimi@abv.bg
}

Recibido: Diciembre de 2011

Aceptado: Febrero de 2011

\section{Резюме}

Статията е посветена на словообразувателните средства при абстрактните съществителни имена в българските диалекти. Анализирани са три категории, които в зависимост от вида на основата, илюстрират системата на диалектните абстрактни съществителни имена, образувани чрез суфиксация: десубстантивни, деадективни и девербативни образувания. В рамките на категориите са описани и основните словообразувателни типове, характерни за абстрактните съществителни имена в българските диалекти.

Ключови думи: абстрактна лексика, словообразувателни модели, български диалекти.

\section{Resumen}

Sustantivos abstractos derivados en los dialectos búlgaros

El artículo estudia los modelos derivativos de los sustantivos abstractos en los dialectos búlgaros. Se analizan tres categorías según su tema: desubstantivos, deadjetivos y deverbativos. Se describen los modelos y sufijos derivativos principales, típicos para los sustantivos abstractos en los dialectos búlgaros.

Palabras claves: léxico abstracto, modelos derivativos, dialectos búlgaros.

\section{Abstract Nouns Formed by Word Formation in Bulgarian Dialects}

\begin{abstract}
The paper deals with word forming means for abstract nouns in Bulgarian dialects. Three categories are analyzed which illustrate the abstract dialect nouns system, formed by suffixation: desubstantial formations, deadjective formations ad deverbial formations. The main word formation types typical for abstract dialect nouns are described.
\end{abstract}

Key words: abstract nouns, word formation models, Bulgarian dialects. 
Повишеният интерес към диалектната лексика намира израз в разработването на редица теоретични проблеми, свързани с лексиката като структурно организирана система, тематично и семантично диференцирана. Описват се отделните парадигми от думи, изработват се методи за структуриране на диалектните лексикални единици. Днес не може да се говори за сериозно диалектно проучване, което не описва и анализира лексикалната система на диалекта (в рамките на самия диалект, в съпоставка с други диалекти или с книжовния български език и останалите славянски езици).

В контекста на сериозните проучвания на предметно-тематични лексикални групи (роднинска терминология, селскостопанска терминология, обредна терминология и др.), на ареалните характеристики и географското разпределение на различни диалектни названия обект на изследване са абстрактните съществителни имена в българските диалекти, които досега не са били предмет на цялостно проучване.

Основни отношения в словообразувателната система са производността и мотивацията, за които в лингвистичната литература съществуват известни различия в интерпретацията им.

На първо място се прави разлика между производност на синхронно и на диахронно равнище. В синхронния анализ производността се установява въз основа на формално-семантичното съотнасяне между две (или повече) думи, свободно функциониращи в езика в определен етап от неговото развитие; синхронното словообразуване изучава само живите връзки между единиците (вж. по-подробно ЗЕМСКАЯ 1973: 7, 10; ВАШАКОВА 1988 и др.). Резултатите от диахронния и синхронния анализ невинаги съвпадат, понякога дори съществено се различават (УЛУХАНОВ 1992). Това дава основания за ясно разграничаване на производността като понятие от диахронното (историческото) словообразуване и мотивацията като понятие от синхронното словообразуване (УЛУХАНОВ 1992).

Трудности при установяването на производността и посоката на мотивация създават диалектните лексикални единици, както и заетите думи, включени в деривационния процес. Въпросът за мястото на чуждите (заети) думи в синхронните и в диахронните словообразувателни изследвания е един от найспорните и нерешени въпроси в теорията на словообразуването.

В диалектите е напълно закономерен процесът на чуждо влияние и тук не става дума само за смесените райони, в които то е обяснимо, но и за зони, в които по ред исторически, езикови, социални причини днес са запазени голям брой чужди названия за абстрактни понятия. Така например за думата вина в българските диалекти се срещат 5-6 названия от народен произход. Те са с ясна мотивация (грешка, кривина и др.), докато всички останали названия са наследени от турския език (лексемата кабахат и нейните фонетични, акцентни и словообразувателни разновидности). Като интересен пример може да бъде посочена лексиката на банатския говор, описана като система от Ст. Стойков. Регистрирани са редица влияния, които са резултат от сложните социални, политически и икономически въздействия, контакти и позиции. Многократно е посочвано в научната литература, че банатските българи не са единни по про- 
изход. Едни са от Чипровско, други са от Никополско, но говорно се отнасят към югоизточните български диалекти. Откъснати териториално, те се развиват самостоятелно, като изпитват силно влияние от страна на румънски, сръбски, хърватски и немски език. Важно е да се уточни също, че заемките не навлизат по еднакъв начин и по едно и също време в диалектите, а са резултат от политически, социални, исторически и културни условия.

В областта на абстрактната лексика Ст. Стойков посочва следните групи. На първо място е отделена абстрактна лексика, която е повлияна от сърбохърватския език. Тук влизат лексеми като брига (грижа, мисъл), зафалнос, фала (благодарност), несрекя (нещастие), срекя (щастие, а н някои български диалекти любов), узрок (причина, повод), фалинка (липса, недостатьк), тужба (оплакване, жалба), тайнус (тайна), лакумус (алчност), напас (изкушение), светлус (светлина). Част от тази лексика се открива и в говорите на територията на Република България, но назовава други понятия или функционира с други словообразувателни модели. Наблюдава се засилена употреба на форманта - ocm: вредднус (стойност), зафавнус (благодарност), пубожнус (набожност), тайнус (тайна). От румънско влияние са лексеми като путера, nутере (сила, мощ), накас (яд, грижа), пумана (помен, задушница) и др. От немски език са останали названия като фелер (недостатьк), имак (вкус), изи (цел). При тези лексеми единствено семантиката указва параметрите и влиянието лесно може да бъде уточнено. Значително е влиянието на унгарските заемки: хазна (полза, печалба), бай (недостатьк), мулатшајк (веселие, забава), алдамаји (черпня, почерпка при сделка), преш (натиск), алдуф (помен, дар, жертва за бог да прости).

На пръв поглед различаването на „домашен“ и „чужд“ лексикален пласт няма отношение към синхронното словообразуване, тъй като опозицията „свое чуждо“ е опозиция предимно на диахронно равнище (чрез нея се набляга на произхода на думата). Вероятно това е причината в словообразувателните изследвания често да не се прави разграничение между двата лексикални пласта - още повече, че „попаднало в системата на езика, чуждоезиковото явление се стреми да се нагоди към нея, т. е. да се освободи от допълнителната си маркировка, за да започне да функционира като неин съставен елемент“ (МУРДАРОВ 1978: 123). От друга страна обаче, в езика съществуват признаци, по които могат да се разграничат (макар и в нееднаква степен) различните по произход лексикални пластове и на чисто синхронно равнище - и то не само по отношение на фонемната и морфемната им структура, на морфонологичните им особености, на съотношението между правопис и изговор (на които най-често се обрьща внимание от изследователите), но и по отношение на словообразувателната им структура (МУРДАРОВ 1978: 123; ВАШАКОВА 1988). Можем само да добавим, че приемствеността най-лесно се открива чрез анализ на формалната структура (например при формантите ост, -ота и др.).

Очевидно проблемът за производността при заетите думи не може да се реши чрез механично прилагане на критериите, валидни при домашната лексика. Както беше посочено, основна трудност при синхронния словообразувателен анализ е да се установи кога става выпрос за образуване на 
домашна почва от чужди компоненти, т. е. кога има наличие на същински словообразувателен процес, и кога само за адаптиране на чуждата формация към домашната словообразувателна система (което се отнася с още по-голяма сила за прилагателните имена). Това от своя страна е тясно свързано с проблема за определянето на инвентара от словообразувателни средства (афикси), т. е. с отговор на въпроса кога даден афикс, който е словообразувателно средство в чуждия език, придобива същия статут и в езика-приемник.

Важно е да се отбележи, че слоовобразувателните форманти също търпят развитие:

- Усвояват се чуждоезикови словообразувателни средства;

- $\quad$ Морфеми от сложни думи или основи разширяват функциите си и придобиват статут на словообразувателни средства.

Като основен критерий за разграничаването на префиксоидите от радиксоидите се приемат опозициите предметно непредметно, конкретно абстрактно в тяхното значение. Радиксоидите изразяват предметно значение (в широк смисъл), но много по-обобщено в сравнение със същинските корени. Префиксоидите от своя страна нямат предметно значение, най-общо изразяват отношения (локативни, темпорални, оценъчни, количествени, отношения на противопоставяне, йерархия), параметри (степен на признак) и др. По това те приличат на префиксите, които също нямат предметно значение (АВРАМОВА 2003).

Като основен словообразувателен способ при абстрактната лексика се използва суфиксацията, която е най-типична за имената изобщо. Като произвеждащи основи при словообразувателния процес в този случай биват използвани основи на съществителни, прилагателни и глаголи (КАЛДИЕВА-ЗАХАРИЕВА 1984:98). Според вида на основата отвлечените съществителни, образувани чрез суфиксация, се разделят на три категории: десубстантивни образувания, деадективни образувания и девербативни образувания. В границите на всяка категория новите думи се създават с определени суфикси, които са активни елементи в процеса на словообразуването. В зависимост от словообразувателния суфикс образуванията в отделни категории се обединяват в словообразувателни типове.

В категорията десубстантивни формации, характерни за диалектите, са словообразувателните типове със суфиксите -лък и -лук, които са от турски произход. В книжовния език са ограничили своята употреба, имат конотативно осмислени значения и синонимно са заменими със суфикса -ство; -ество (хайдутлук-хайдутство, ергенльк-ергенство и др.).

При деадективните образувания активност в диалектите проявяват суфиксите -uна и -ота, - ост и -ecm. Продуктивност в по-слаба степен в сравнение с книжовния език показва суфиксът -ие. В сравнение с реализацията в книжовния език суфиксът -да се включва като компонент в редица абстрактни диалектни съществителни имена (правда, кривда и др.). Изключително продуктивен в диалектите е и суфиксът -отия, с който в книжовния език се офор- 
мят структури с конотация за негативизъм (простотия, дивотия, леснотия, мъчнотия, беднотия и др.).

При девербативите се обособяват следните словообразувателни типове:

- Производните със суфикс -не и неговите диалектни фонетични разновидности заемат основно място и се характеризират с широка употреба.

- Словообразувателният тип със суфикс -ние обхваща съшествителни, които не са синоними по отношение на девербативите с -не. В диалектите рядко се постига синонимия между производни с двата суфикса. Основната конкуренция, породена от фонетични различия, е между суфиксите -не и -нье.

- Суфиксите -ба, - итба, -еж, -ка, -иц̧а, - ня, -ък, -от, -ия проявяват голямо фонетично разнообразие в диалектите.

На базата на семантичните характеристики най-общо диалектните абстрактни съществителни имена могат да бъдат разделени на следните групи:

1. Производни структури, сходни по семантика с абстрактните имена в книжовния език. Тяхното наличие е напълно нормално, като се има предвид, че през Възраждането диалектите и отчасти черковнославянският език реактуализират старобългарски лексикални пластове и подпомагат навлизането на абстрактна лексика за нуждите на оформящия се книжовен език. Различията тук се свеждат до спецификата и облика на словообразувателния компонент, като най-често промяната е обусловена от фонетичното разнообразие в диалектите благота, благуть - за 'добрина'. В съвременния език думата благо е развила по-специализирано значение, свързано с придобиване на материални облаги, което отдалечава семантиката в сравнение с диалектите; добрина; орисия - 'съдба'; бърканица, батак, битпазар - за 'безредие', в книжовния език са стилистично маркирани или имат специализирана и ограничена стилово употреба; неволя, орис - за 'сьдба'.

2. Характерни (частни) диалектни абстрактни съществителни имена - блуд - 'безредие', намера, болест, патеж, патилка, наказия, пендяк - за 'беда'; разтурия, бъркотия, мотаница, олелия - за 'безредие';

2.1. Със значения, различни от книжовноезиковите: разсипница (Добралък, Яврово, Асеновградско), злина' - болест, бардак за 'безредие', нужда за 'болест' (Гайтанево, Софийско), бодеж за название на мъчително усещане, причинено от някакво телесно страдание, болка (Кипилово, Сливенско); зулум за название на болка (Върбица, Преславско).

$2.2 \mathrm{C}$ различно значение в рамките на отделните диалекти: таксират - зла съдба (Горна Джумая), сотра’ - зла съдба (Банско, Разложко), изрок - зла съдба (Банско), сетра - зла съдба (Елин Пелин), сугара - лоша съдба (Странджански говори), некас- тежка съдба, нещастие (Крислово, Пловдивско). Към тази подгрупа могат да бъдат причислени и някои интересни абстрактни диалектни съществителни имена, чрез които се подчертава фазовост или край: връвачка - болест, която минава много бързо (Дебър); редня - болест в лека форма (Негованци, Видинско), страдалос - изживяно страдание, или за по-специфични случаи, чрез които се маркира определеност: заврат- болка във врата 
(Славеино, Смолянско); кръчак- болка в краката (Малорад, Оряховско).

3. Абстрактните диалектни съществителни имена, резултат от чуждоезиково влияние, се характеризират със силно разнообразие на словообразувателната оформеност, а от друга страна, показват многообразие в семантичен план: cебап (Гостилица), селемет (Баница, Сяр); хаир (Варненско-Венчан, Павликенско-Михалци, Хасковско-Сусам, Разложко - Долно Драглище), аир (Батишница, Широки дол, Тополница, Сливница), мерхамет (Смолянско, Ардинско, Асеновградско, Девинско) и фонетичните разновидности; кабахат, кабахајк, кабахек, кабах⿱ и други фонетични облици се използват за название на постъпка или действие с лоши последствия, провинение, грешка. Разпространени в отделни диалекти са названията харам (Преславско); за съдба - таксират (Горна Джумая), тексират, тексерат (Разлог, Арда, Смолянско); дередже (Новачене, Ботевградско); за название на болест - кедер (Малко Търново), заамет (Армени, Габровско).

4. Експресивни названия, част от които се използват в книжовния език със стилистична или прагматична функция, а други функционират само в диалектите за название на съответната „реалия”: алак-булак - за “безредие’ (Голям извор, Разградско), абур-джубур - за 'безредие' (Тикв), какафония- (Добри дял, Великотърновско), галимация (Асеновградско), калабалък (Нивянин,Врачанско), нагьотере (Ясна поляна, Бургаско), тупурдия (Жеравна), олелия (Койнаре, Бяла Слатина), шамарма̀, шумотевица, гол, чи гладен за 'беден', миш-маш за 'безредие' (Търнак, Белослатинско), ичганско джамбало (Големаново, Кул), фукария (Радовене, Врачанско), за зла врага (Еленско); болярка ‘болест’ (Стралджа, Ямболско); тантела марка (Бракница, Поповско), шашарма', шашма, шаш, измишлетина, партенка, ветар и мъгла, бош лаф, уйдурма за 'лъжа' и др.

На базата на словообразувателните особености най-общо диалектните абстрактни съществителни имена могат да бъдат групирани по следния начин:

1. Десубстантивни формации.

Най-характерен за диалектите е словообразувателният тип със суфиксите

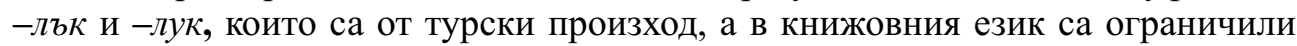
своята употреба. Производните имат конотативни значения и се конкурират с формации със суфикса -cmво. В тази група разнообразието е изключително голямо и затова ще посочим само част от примерите от ексцерпирания материал: за 'безредие': амалък (Крушево, Хисарско), бузгунлук (Александрово, Ловешко), карашманльк (Еленско), калабальк (Нивянин, Врачанско), за'беда и бедност'- аталък (Нова Ловча), бузгунлук (Белица, Добърско, също и в Разложко), патлък (Ново село, Троянско), сиромашлък, сирумашилък, сюрмашлък (Русенско, Горнооряховско); название на 'болест' асталък (Ардино, Девин, Смолян), виранлък (Енина, Шейново, Казанлъшко), тевекеллък название на 'добрина' (Странджанско); мизерлък (Крупник, Благоевградско), домакинлък (Кюстендилско), мунафлък (Копривщица) и др.

2. Деадективни образувания.

Активност в диалектите проявяват суфиксите -ина -ота и -осm. 
Изключително продуктивен е и суфиксът -ия и неговият разширен вариант -отия (леснотия, мъчнотия, беднотия).

Формациите със суфиксите - ина, - ия, -ост и -ота отразяват различни диалектни фонетични особености, но в същото време запазват семантична близост с лексиката на книжовния език: добрина (Варвара, Пазарджишко), благос (Белослатинско, Ломско); страдаллос (Смочево, Гоце Делчев), благуть (Пожарево, Тутраканско), сладчина (Котелско); харнота, харнотия (Пьрвомайско); судбина (Ихтиман); болесчина (Расово, Ломско), неелищчина, нелитиня (Тръстеник, Плевенско), нефелнина (Велинград); гелпутина (Странджанско), тунина (Дреново, Яково, Петричко/, бедётина (Извор, Рад), кривина (Овчеполци, Пазарджишко, Сяр); названия на 'лъжа' -шъмътия (Ичера, Сливенско); добротия (Крьвеник, Севлиевско), болнотия (Костенец); бръкония (Долно Левски), бъкотия (Крислово, Пловдивско), пустакия (Подлес, Силистренско) и др. Като словообразувателно оформени се осъзнават и абстрактните съществителни като месалия (Широка Лька, Девинско), лакардия (Софрониево, Оряховско); орисия (Долна Митрополия, Тръстеник, Плевенско; Драговищица, Софийско; Старо село, Сливенско), дандания (Скравена, Ботевградско); хаталия (Паталеница, Пазарджишко); сакантия (Костенец, Ихтиманско) и др.

Характерният за славянските езици суфикс -ост заслужава малко по-специално внимание, тъй като освен в диалектите, проявява активност и в книжовния език, като се разширява крьгьт на произвеждащите основи, с които се съчетава. Традиционната му дистрибуция е свързана с непроизводни прилагателни, които най-често означават вътрешно присъщи качества (глупав, луд, хубав) и образуват деадективни съществителни, назоваващи абстрактни понятия. В съвременния български език особено продуктивен е модельт, при който произвеждащата дума е прилагателно със суфикс -ен: иелесъобразен - иелесъобразност, наукообразен -наукообразност, безотговорен - безотговорност. През последните години в българския език се засилва употребата на абстрактни съществителни имена със суфикс -ост, при които мотивиращата основа не е качествено прилагателно име: заедност, другост, чуждост, полскост, чешкост, балканскост, българскост и др. В диалектите суфиксът -ост също проявява активност и се среща често: зафалнос (благодарност), тайнус (тайна), лакумус (алчност), светлус (светлина), вредднус (стойност), зафавнус (благодарност), пубољжнус (набожност), тайнус (тайна), милост (за 'любов' в Ново село, Видинско) и др.

3. Девербативи.

В тази група се включват следните словообразувателни типове:

3.1. Отглаголните съществителни със суфикс - не и неговите фонетични разновидности заемат важно място в българските диалекти със своята регуларност и честота на употреба: пакостѐнье (Самоковско), стурине (Граматиково, Малко Търново), неммане (Варвара, Пазарджишко), неманье (Стакевци, Белгр), нимане (Малчика, Свищовско), подадене (Вардун, Търговишко), лъгане, лъгосване (Хасково), либене (Букьовци, Оряовско), галяне (Устово, Смолянско), милуене/милуване (СБНУ ХХ), пакостене/пакос- 
тѐне (Самоковско), сподадинѐ (Дрента, Еленско), докајрване, дрѐмане и др.

При конкуренцията между суфиксите -не и -ние моделът със суфикс -не е по-характерен за диалектите, откъдето се налага и в книжовния език. В писмената практика също е предпочитан този суфикс, най-вероятно поради засилената честота на употреба в народните говори - още през XVII и XVIII век в дамаскините се срещат девербални съществителни като теглене, очистене, ядене (Тихонравов дамаскин); заръчане, льстене, съмнуване, имане, чакане (Копривщенски дамаскин); думане, приказуване, боене (Свищовски дамаскин).

3.2. Суфиксите -ба, - итба, -еж, -ка, -ица, - ня, -ък, -от, -аж, -ик и др. показват по-ограничена употреба при образуване на абстрактпи имена: бедаж (Долене, Петричко), патилка (Смочево), патеж (Габров дол, Брезнишко), бърлок (Кръвеник, Севлиевско), енгелик 'лъжа', (Жеравна), масал (Гоце Делчев), инкяр (Ново Паничарево, Бургас; Винарско, Айтос), пукот, сръдня, караница, брътвёж, даваница, делитба (Долни Дъбник, Петьрница, Плевенско), сръдня, свирня, лигня и др.

3.3. Абстрактни диалектни съществителни имена с нулева суфиксация или съкратени основи: издих - въздишка (Брезник), мор - за 'смърт по животните' (Плевенско) и за 'жега', пек (Долни Дьбник, Плевенско), сюрмаш, најмек, упрек, огрев, посев, помен, приказ, разплод, уплах, откат (отмаляване) и др. Произвеждащите глаголи са префигирани. Определено място заемат производните структури от транспозиционен ономасиологичен тип. Абстрактното им значение е свързано с пренасянето и преминаването на понятието, означено от мотивиращата дума, към 'друга понятийна категория’, характеризирана с нетипична езикова особеност (например в дърва за огрев съществителното огрев съдържа белега 'процесуалност', но абстрахирани от 'време' и 'носител'). Това прави възможна употребата и в различни семантични схеми с цел: семена за посев, добитък за разплод, стока за продав/продан и др. В случая се наблюдава употреба както на домашни, така и на заети думи с абстрактно значение.

3.4. Словообразувателни типове, фиксирани в художествените текстове:

3.4.1. Наставката -льк е възприета като словообразувателен елемент в думи от арабски и турски произход, но се свързва с десубстантивни основи от домашен произход за образуване на nomina essendi, с които се означава абстрахирано качество (особеност, занятие) на лицето, посочено от мотивиращото съществително име (РАДЕВА 2007: 136): ловджия - ловджильк, авджия авджильк; майстор -майсторлък; даскал - даскалльк; гурбетчия - гурбетчильк; човек, човещина -човечлък и др. Суфикс -льк е зает заедно с турски или арабски думи и е характерен само за новобългарския език.

3.4.2. Наставката -uн(a) се свързва с названия с мотивиращи основи от качествени прилагателни имена. Произвеждащите основи, които завършват на веларен звук, участват в деривацията с морфонологично редуване пред суфикса $-u н(a)$. В зависимост от качеството, което изразяват, названията се обособяват в няколко групи:

- $\quad$ за качества и състояния: горещзина, тъмнина, усилнина и др.

- названия за физически качества и размер: дължина, дълбина и др.

- названия за душевни качества: нефелнина, лютина, изеднина и др. 
Известно е, че в сравнение с лексиката на книжовния български език диалектите разполагат с по-малко на брой абстрактни лексикални единици. В същото време различните думи за абстрактни понятия в диалектите свидетелстват за тенденцията към вътрешна диференциация, т.е за наличието на т. нар. частни диалектни системни различия. (ОССОВЕЦКИ 1964:77-80, цит. по РАДЕВА 2001:112):

Употребата на регионално ограничени думи е специфична особеност, която създава усещането за екзотичност и автентичност на текста. В много случаи с цел да се придаде и конотативен характер значенията на редица думи, познати на книжовния език, се изразяват с производни структури, оформени по диалектни словообразувателни модели. В българския език например наред със съществителното име бедност се употребяват названия като нямане, мизерия, сиромашия, гладория, беднотия, сиромашлък и др. Част от тях функционират като контекстови синоними, а други се използват в по-специфичен контекст с разширено или специализирано значение. В българските говори се срещат още названия като босоча, прекания, сакантия, вакарльк, фукария и др. Тези диалектизми, определяни в лингвистичната литература като номинационни (терминологични), са резултат от сложната взаимовръзка между извънезиковата действителност и развитието на езика, чрез което се мотивира лексикалната диференциация в диалектите (СТОЙКОВ 1963: 107). В художествените текстове намират реализация голям брой абстрактни названия, които са стилистично маркирани: арашлък - харачльк, бозгун - размирица, брига - грижа, гайле - грижа, гьозбояджильк - шарлатанство, мошеничество, измама, гьовезельк - глезотия, кокетство, даян - издръжливост, тьрпение, джан, жан душа, долондърджилък - измамничество, мошеничество и др. По-голяма част от тях са от турски произход и днес се пазят предимно в диалектите, но са с неясна, избледняла семантика и служат с експресивна функция в книжовния език. Други пък като гюрултия, даскаллък, хъз, гайле /от турски и от гръцки език/, войникльк, ергенлък са познати, но се употребяват само като маркирани единици и носят съответното експресивно значение.

Към словообразувателните диалектизми принадлежат думите, оформени с диалектна произвеждаща основа: прекания, сакантия и др. Лексемата беднотия е образувана със специфичния за nomina abstracta суфикс -отия (-отийа), който се среща още в старобългарския, а днес е особено актуален за образуване на абстрактни съществителни имена, паралелно с други суфикси за абстрактни имена: глупост - глупотия, бедност - беднотия, пошлост - пошлотия, тежкотия, доброта - добротия, старост -старотия и др., с които се назовават отрицателни признаци и свойства и изразяват неодобрителност, пряко свързана със семантиката на мотивиращите прилагателни. Абстрактните съществителни имена, образувани с тази наставка, най-често са мотивирани от качествени прилагателни имена. Непроизводните прилагателни имена, които мотивират абстрактни названия, се включват изцяло в производната основа прост:простотия (РАДЕВА 1991: 144), а производните ськращават основата си с изпадане на гласната от суфикса им: беден - бедн/отия, тежък тежк/отия и др. 
Диалектната абстрактна лексика, която разкрива богатството на българските говори, показва разнообразие от фонетични варианти и словообразувателни модели, включва непрозрачни думи, чиято мотивираща основа не е ясна за съвременното езиково съзнание, и преосмислени (адаптирани) думи и форми, резултат от чуждоезиково влияние.

Създаването и употребата на абстрактна лексика в диалектите са обусловени от стремежа да се концептуализира и отрази в езика вьтрешният мир на човека, да се осмисли това, което не се наблюдава и възприема перцептивно. Затова голяма част от абстрактната лексика семантично се свързва с концепти, интерпретирани като семантични универсалии.

Отнесени към концептуалната картина на света, те отразяват универсалната за носителите на различни езици (включително диалекти) необходимост да се разграничи 'добро' от 'зло', 'приятно' от 'неприятно', 'приемливо от неприемливо', а осъзнаването на това противопоставяне регулира поведението и отношението на хората в обществото.

\section{Библиография}

АВРАМОВА,Ц.(2003): Словообразувателни тенденции при съществителните имена в българския и чешкия език в края на ХХ век, Издателство „Херон Прес”, София.

ВАШАКОВА, К. (1988): "Slowotworstwo rzeczownikow oblych - synchroniczne znamiona obcosci derywatow sufiksalnych", Polonica, XIII, 131-140.

ЗЕМСКАЯ, Е.А. (1973): Современный русский язык. Словообразование, Просвещение, Москва.

КАЛДИЕВА-ЗАХАРИЕВА, Ст. (1984): „Абстрактната лексика- богатство на съвременния български книжовен език”, Съвременна България, т. 5, БАН, София, с.98.

МУРДАРОВ, Вл. (1978): „Интерпретация на чуждоезикови формации в българската словообразувателна система. (С оглед към субстантивите, съдържащи суфикса -ист)", Славистичен сборник, Издателство на БАН, София.

РАДЕВА, В. (1991): Словообразуването в българския книжовен език, УИ „Св. Климент Охридски", София.

РАДЕВА, В. (2001): Увод в ареалната лингвистика, УИ „Св. Климент Охридски”, София.

РАДЕВА, В. (2007): В света на думите, УИ „Св. Климент Охридски”, София.

СТОЙКОВ, Ст. (1993): Българска диалектология, Издателство на БАН, София.

УЛУХАНОВ, И.С. (1992): „Мотивация и производность (о возможностях синхронно диахронического описания языка)", Вопросы языкознания, №2, Москва, 5-20. 